\title{
Homoseksuelles medborgerskab i et retfærdigheds- perspektiv
}

\section{Af Christel Stormhøj}

I bvilken grad er homoseksuelle lige og fulde medborgere $i$ Danmark? Ud fra teorier om medborgerskab og retfardighed belyses en rakke kultuvelle, politiske, retslige, økonomiske og moralske begransninger af homoseksuelles medborgerskab.

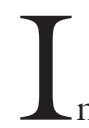

nternationalt opfattes Danmark som et foregangsland, når det gælder inklusion af homoseksuelle. ${ }^{1}$ Man hæfter sig ved den udstrakte retslige ligestilling med heteroseksuelle, den omfattende sociale accept af homoseksualitet i befolkningen og at mange homoseksuelle lever offentligt åbent. Forestillingen om Danmark som et seksuelt ligestillende samfund gennemsyrer også den brede offentlighed og store dele af det politiske system nationalt (Albæk 1998). Samfundet bygger på gensidig respekt og forståelse mellem grupper, og det accepterer ikke intolerance, diskrimination og vold på grund af seksuel orientering. ${ }^{2}$

Spørgsmålet er, om disse forestillinger svarer overens med virkeligheden. I hvilken grad er homoseksuelle fulde og lige samfundsmedlemmer? Dette spørgsmål adresseres almindeligvis inden for en medborgerskabsoptik, ${ }^{3}$ der fokuserer på individuelle rettigheder og pligter, inklusion i en national kultur og deltagelse i udøvelse af poli- 
tisk magt inden for et frllesskab. I dansk forskning er der kun få studier af homoseksuelles medborgerskab, ligesom der kun er sporadiske ansatser til at anlægge et retfærdighedsperspektiv herpå (se f.eks. Albæk 1998, Stormhøj 2002, Ussing 2002). Seksualitetsteoretikere har udviklet forskellige teorier og konkurrerende visioner om et fuldt og lige medborgerskab for homoseksuelle (f.eks. Phelan 2001, Seidman 1997). Et centralt omdrejningspunkt har været at analysere de institutionelle barrierer i samfundet, der begrænser homoseksuelles adgang til et fuldt og lige medborgerskab.

I forlængelse af denne tradition er ærindet med artiklen dels at skitsere en analytisk og normativ ramme for et retfærdigt seksuelt medborgerskab, ${ }^{4}$ der kombinerer elementer fra teorier om medborgerskab og social retfærdighed med henblik på at opnå en mere komplet forståelse af den flerhed af barrierer, der forhindrer et sådant. Dels at lægge denne ramme til grund for en analyse og kritik af begrænsninger af homoseksuelles medborgerskab. Tilgængeligt empirisk materiale fra en dansk kontekst bruges som illustrative eksempler. Pointen med at diskutere homoseksuelles medborgerskab i et retfærdighedsperspektiv er, at der kan fældes domme over samfundet på en begrundet måde, dvs. med henvisning til en norm for det retfærdige.

\section{FrugtBARE TEORIER OM \\ ET RETFÆRDIGT SEKSUELT MEDBORGERSKAB}

Det er omstridt i nutidig politisk teori, hvordan samfundet skal være indrettet for at muliggøre et fuldt og lige medborgerskab for alle. Groft skitseret har økonomisk orienterede lighedsteoretikere 5 set retfærdighed som et spørgsmål om en ligelig fordeling af materielle goder, mens kulturelt orienterede forskelsteoretikere ser retfærdighed som anerkendelse af kulturelle forskelligheder. ${ }^{6}$ Imod begge traditioner kan det indvendes, at de med deres ensidige fo- kus på økonomi henholdsvis kultur dels anlægger et reduktivt syn på retfærdighed, dels at de lukker af for at begribe relationerne mellem materielle og immaterielle uretfærdigheder. Derimod udmærker Nancy Frasers (1997, 2003, 2005) retfærdighedsteori sig ved ikke kun at omfatte flere dimensioner af retfærdighed: økonomiske, kulturelle og politiske, men også ved at synliggøre de oftest skjulte overlapninger mellem forskellige former for uretfærdighed, der i praksis er reglen frem for undtagelsen. ${ }^{7}$ Det er mit argument på linje med Fraser, at homoseksuelle ${ }^{8}$ konfronteres med såvel kulturelle, økonomiske som politiske uretfærdigheder - om end ikke i lige høj grad - hvorfor retfærdighed kun kan opnås ved at afhjælpe dem samtidigt. Af disse grunde vil Frasers teori stå centralt i artiklen.

Medborgerskab er et sammensat begreb. Rettigheder og pligter, deltagelse i udøvelse af politisk magt samt kulturel inklusion er lige uundværlige momenter, hvis borgerne skal kunne se sig som fulde samfundsmedlemmer. Shane Phelans (2001) teori om medborgerskab er kendetegnet ved at fastholde denne kompleksitet. ${ }^{9}$ Endvidere udvikler hun en vision om et inkluderende og demokratisk medborgerskab for homoseksuelle, der bygger på anerkendelse. Med afsæt i hendes idé om medborgerskab som anerkendelse, ${ }^{10}$ vil jeg selvom idéen endnu ikke er fuldt udviklet, argumentere for, at anerkendelse er selve forudsætningen for fulde rettigheder, inklusion i den nationale kultur samt demokratisk medbestemmelse i forhold til det fælles. Derfor inddrages hendes teori i min analytiske og normative ramme.

Hvor Fraser betoner retfærdighed som en dyd ved samfundsindretningen, lægger Phelan vægt på retfærdighed som en dyd ved medborgerskabet, især ved borgernes forpligtelser over for hinanden. Ved at kombinere de to retfærdighedsbegreber fremvises retfærdighed som en dyd ved både sociale institutioner og medborgerskab. 
MEDBORGERSKAB SOM ANERKENDELSE

Anerkendelsell er grundlaget for et fuldt og lige medborgerskab ifølge Phelan. Anerkendelse refererer til at blive set af andre borgere og staten, at have respekt for andre borgeres rettigheder, krav og status samt at deltage på lige fod med andre i det offentlige liv (Phelan 2001: 14). I relation til inklusion i det hegemoniske, nationale forestillingsunivers, dvs. den række af billeder, symboler og retorikker, der udgør grundlaget for den kollektive nationale identitet og befolkningens selvforståelse (ibid. 2001: 7), betyder anerkendelse udvikling af en kulturel anerkendelsesrelation såvel mellem stat og medborgere som indbyrdes mellem medborgerne. At være anerkendt indebærer, at man har en ligeværdig plads i den nationale kultur og identitet.

Adgang til rettigheder forudsætter, at den enkelte er anerkendt som et medlem af staten. Anerkendelse indebærer her, at der etableres en særlig relation mellem staten og individerne, der udtrykkes i form af retslig anerkendelse, og som fører til, at borgeren udstyres med de samme rettigheder som alle og enhver (ibid. 2001:16).

Deltagelse i det politiske frllesskab forudsætter, at ens tilstedeværelse er anerkendt af andre og af staten (ibid. 2001:17). Her betyder anerkendelse udvikling af en politisk anerkendelsesrelation, der sætter én i stand til at deltage og artikulere ens interesser som offentlige anliggender og at blive lyttet til og svaret på lige vilkår med andre. Politisk anerkendelse handler om inklusion i det offentlige liv og retten til fuld deltagelse i beslutningsprocesser om det fælles, herunder at være medforfatter til lovgivning.

Kun en offentlig kultur, der bygger på en solidarisk etos mellem seksuel minoritet og majoritet, kan befordre et fuldt og lige medborgerskab for homoseksuelle (ibid. 2001: 139). Grundlaget for borgernes ageren i fællesskab er ved siden af tilslutning til dialog og drøftelse en principiel bekræftelse af seksuel forskellighed i form af en villig- hed til at forstå forskelle som frugtbare frem for som trusler mod det politiske fællesskabs enhed. Især fordrer den solidariske etos, at den heteroseksuelle majoritets selvforståelse tillades at blive forandret i nærværet af den anden. Det indebærer en 'omplacering' af forskellens plads. Frem for en placering af forskellen hos minoriteten, der fører til fortsat 'andetgørelse', kræver det en forståelse af forskel som værende af afgørende betydning for alles identiteter på tværs af spektret af seksualiteter. Kun derved kan grænsen mellem heteroseksuelle og homoseksuelle opblødes. Endvidere rummer tilslutningen til dialog og drøftelse muligheden for, at medborgerne udvikler gensidig forståelse og indbyrdes solidaritet, hvorved der kan skabes nye fælles identiteter, der integrerer forskelligheder.

Ifølge Phelan vil homoseksuelle forblive marginale medborgere, hvis ikke de opnår den fulde kulturelle, retslige og politiske anerkendelse, som på sin side kun kan fremmes gennem gensidig respekt mellem borgerne. Imidlertid er hendes begreb om anerkendelse underteoretiseret, ligesom hun savner en robust begrundelse for den lighedsnorm, hun påkalder sig. For at udbedre disse mangler samt for at placere seksuelt medborgerskab i et retfærdighedsperspektiv skitseres i det følgende de elementer i Frasers teori, som indgår i min begrebsramme.

\section{EN UDVIDET TEORI} OM RETFÆRDIGHED

'Lighed i deltagelse' i samfundet i bred forstand er indbegrebet af retfærdighed for Fraser (Fraser 2003a: 36). Normen begrundes abstrakt ved henvisning til menneskers moralske ligeværd samt kontekstuelt som resultat af en historisk fortolkningsproces i Vesten, hvor dens gyldighed gradvist er blevet udstrakt til flere befolkningsgrupper og til større og større dele af det sociale liv (Fraser 2003b: 231). Ud fra denne norm kan det vurderes, i hvilken ud- 
strækning samfundets institutionelle betingelser muliggør eller forhindrer retfærdighed. Grundlaget herfor er en analyse af det aktuelle vestlige, kapitalistiske samfunds hierarkiske ordener, der udfoldes i form af en 'triple perspektivisme'. ${ }^{12}$

Uligheder i den økonomiske orden resulterer i en ulige fordeling af ressourcer og byrder, hvilket krænker retfærdigheden, da nogle mennesker nægtes forudsætningerne for at deltage på lige fod i det sociale liv. Økonomisk omfordeling er derfor nødvendig.

Værdimønstre i den kulturelle orden giver ophav til asymmetriske anerkendelsesrelationer mellem grupper, hvorved statusforskelle opstår. Disse er brud på retfærdigheden, da de nægter nogle mennesker status som fuldgyldige deltagere i det fælles liv. For at tilvejebringe retfærdighed kræves ændring af værdimønstrene, således at de udtrykker lige respekt for alle. Anerkendelse ses altså som statuslighed og ikke, som det er tilfældet blandt forskelsteoretikere, som valorisering af individuelle eller kollektive identiteter.

Relevant for min problemstilling er analysen af den heterosexisme, der udspringer af de kulturelle værdimønstre, og som implicerer en privilegering af heteroseksualitet samt en miskendelse af og despekt for homoseksuelle, hvilket resulterer $\mathrm{i}$ en systemisk undertrykkelse (Fraser 1997: 18, 2003a: 17). De heteronormative værdimønstre forstås som institutionaliseret i og transmitteret gennem offentlige organer, f.eks. lovgivning og velfærdspolitikker, den massemedierede kommunikation samt store dele af hverdagens praksisser. Som jeg har argumenteret for andetsteds, ${ }^{13}$ kan denne analyse ikke umodificeret overføres til danske forhold. Den binære, hierarkiske relation mellem hetero- og homoseksualitet er blevet opblødt i Danmark. Som resultat af et samspil af faktorer, herunder socio-kulturelle moderniseringsprocesser, politisk reguleringstradition og kultur, nationale ideologier, alliancedannelser mellem sociale bevægelser og politiske partier, fravær af stærke anti-homo mobiliseringer (folkeligt, religiøst, statsligt) etc., er der sket og sker der fortsat en svækkelse af heteronormative værdiers regulative kraft såvel interpersonelt som institutionelt.

Ulige adgang til repræsentation inden for ikke kun den distinkt politiske orden, men bredt inden for de institutionelle rammer, som påvirker samfundsmedlemmernes handlemuligheder, resulterer i politisk marginalisering eller misrepresentation (Fraser 2003a: 67, 2005: 3). Denne er en krænkelse af retfærdigheden, da den nægter nogle mennesker lighed $i$ adgang til offentlige drøftelser og beslutningstagen om det fælles. ${ }^{14}$ Uretfærdighed afhjælpes gennem demokratisering.

Kardinalpunktet i triple perspektivisme er, at enhver praksis skal behandles på samme tid som kulturel, økonomisk og politisk (Fraser 2003a: 63). Pointen er tillige, at de forskellige undertrykkelsesformer gensidigt kan forstærke hinanden og skabe 'onde cirkler'.

\section{ANALYSE AF HOMOSEKSUELLES MEDBORGERSKAB}

Ud fra Frasers triple perspektivisme samt i lyset af Phelans skelnen mellem kulturel, retslig og politisk anerkendelse vil jeg efterfølgende holde en række empiriske eksempler på anerkendelse og miskendelse, omfordeling og misfordeling samt politisk repræsentation og misrepræsentation af homoseksuelle op imod normen om lighed i deltagelse. Målet er en kritisk vurdering af, om samfundsindretningen og de mellemmenneskelige relationer har en sådan karakter, at de sikrer frem for at underminere betingelserne for et retfærdigt seksuelt medborgerskab. Eksemplerne koncentrerer sig om fire nedslagspunkter. ${ }^{15}$ 
ANERKENDELSE PÅ DET FAMILIE- OG SOCIALRETSLIGE OMRÅDE

Det første punkt angår retslig anerkendelse og handler om det familieretslige område, hvor staten via en rakke love regulerer medborgernes samlivs- og familieformer og dermed deres civilrets-, men også delvis deres socialretsstilling. Lovgivningen er i sin helhed udtryk for en blanding af en retslig anerkendelse af homoseksuelle som medborgere og en miskendelse af dem. Indstiftelsen af det registrerede partnerskab indebærer en statusudligning mellem homo- og heteroseksuelle. Men den række af civile og sociale rettigheder, der eksklusivt knytter sig til den retslige anerkendelse af heteroseksuelle samlivsformer (borgerlig vielse og xgteskab indgået i Folkekirken) implicerer på sin side en miskendelse af homoseksuelle, der betyder indskrænkning af civile rettigheder. Homoseksuelle har ingen ret til fremmedbarnsadoption, med-moderen i et lesbisk forhold har ingen automatisk adgang til stedbarnsadoption, og hun har heller ingen offentlig sikret ret til barselsorlov. Derudover implicerer miskendelsen en reduktion af sociale rettigheder $i$ form af manglende lønkompensation i forbindelse med barselsorlov for med-moderen (Stormhøj 2006). Indtil for ganske nylig var lesbiskes sociale rettigheder også begrænsede $\mathrm{i}$ relation til serviceydelser. Lesbiske havde ikke adgang til offentlig finansieret, lægeassisteret befrugtning (Stormhøj 2006). Konsekvenser heraf var, at lesbiske selv måtte bære de økonomiske omkostninger ved fertilitetsbehandling i Danmark eller udlandet. Hvor sidstnævnte var tilfældet, suppleredes omkostninger ved selve behandlingen af omkostninger i forbindelse med rejse og ophold i udlandet. Eftersom lovkomplekset ikke tildeler homoseksuelle samtlige de rettigheder, der er forbundet med indgåelse af borgerlig vielse eller æxgteskab, opfylder det ikke de fordringer, som retfærdigheden stiller. Effekten heraf er anskuet ud fra anerkendelsesperspektivet statusundertrykkelse, der implicerer indskrænket selvbestemmelse og dermed indskrænkede muligheder for at forfølge egen vision om det gode (familie-) liv. Set fra omfordelingsperspektivet er konsekvenserne nogle økonomiske byrder. Eftersom homoseksuelle ikke kan siges at være sikret en effektiv stemme i fastlæggelse af lovgivningen, og da LBL som social bevægelse er placeret på marginen af systemet af institutionaliserede interessegrupper ( $\mathrm{Pe}$ dersen 2005), er effekterne betragtet ud fra demokratiperspektivet politisk misrepresentation.

\section{ANERKENDELSE I DET CIVILE SAMFUND}

Det andet nedslagspunkt drejer sig om hverdagslige praksisser i det offentlige rum og omhandler den kulturelle anerkendelse mellem medborgere. Miskendelsen kommer til udtryk $\mathrm{i}$ form af vold samt andre former for krænkende overgreb. DrudJensen og Knudsen (2005) rapporterer om en lang række tilfælde af vold imod homoseksuelle uden dog at kunne sige noget om omfanget heraf. Tal fra svenske og norske undersøgelser, der med en vis sandsynlighed kan siges at have en udsigelseskraft også for danske forhold grundet landenes kulturelle ligheder, viser, at omtrent dobbelt så mange lesbiske og over tre gange så mange bøsser har været udsat for trusler om vold, som har sammenhæng med seksuel orientering, i sammenligning med den generelle befolkning (Hegna m.fl. 1999). I Sverige rapporterer 24 pct. af alle lesbiske og 38 pct. af alle homoseksuelle mænd at have været udsat for fysiske eller psykiske krænkelser (Statens Folkhälsainstitut 2005). Vold og den potentielle risiko for vold reducerer gruppens sikkerhed. Set fra et anerkendelsesperspektiv implicerer denne praksis statusundertrykkelse, der alt andet lige reducerer homoseksuelles muligheder for at deltage i det fælles liv på lige fod med andre. Vold og andre overgreb kan resultere i sygemelding, varig legemlig beskadigelse, midlertidig pause i uddannelsesforløb etc. Anskuet i omfordelingsperspektivet kan dis- 
se forhold medføre betydelig indkomstreduktion, udsættelse af færdiggørelse af uddannelse, tab af selvforsørgelsesevne etc. og dermed implicere økonomiske byrder, der i værste fald kan føre til økonomisk deprivation. Praksissen kan betragtet fra demokratiperspektivet resultere i politisk apati.

\section{ANERKENDELSE PÅ ARBEJDSMARKEDET}

Det tredje nedslagspunkt angår inklusion på arbejdsmarkedet. Her handler det også om kulturel anerkendelse. Tilgxngelig forskning tegner et broget billede, hvor der på den ene side er tydelige indicier på anerkendelse, som kan aflæses i form af inklusion og accept af homoseksuelle på arbejdspladsen. ${ }^{16}$ På den anden side peges på miskendelse, der manifesterer sig som chikane, stigmatisering og usynliggørelse. Homoseksuelle rapporterer, at de ikke sjældent oplever problemer $\mathrm{i}$ forhold til at kunne være åbne om deres livsform i samværet med arbejdskolleger og arbejdsgivere på baggrund af frygt for despekt samt andre former for sanktioner, f.eks. manglende forfremmelse og fyring. Dårligere trivsel, stress og sygefravær opstår også som effekter af miskendelse, ligesom det at blive nægtet ansættelse eller at blive fyret på grund af seksuel orientering er konsekvenser heraf. Set fra et anerkendelsesperspektiv er effekten af miskendelse statusundertrykkelse. Anskuet ud fra et omfordelingsperspektiv kan den f.eks. i forbindelse med hyppigt sygefravær medføre indkomstreduktion, eller den kan i værste fald i forbindelse med en uretmæssig fyring betyde økonomisk deprivation, hvis ikke arbejdsgiveren pålægges at yde erstatning. De gensidigt forstærkede relationer mellem miskendelse og mangel på tilstrækkelige økonomiske ressourcer kan på sin side, anskuet i demokratiperspektivet, foranledige opgivelse af deltagelse i politisk arbejde. Det være sig i fagforeningsregi i kampe for repræsentation af homoseksuelle i udvalg, der arbejder med arbejdsmiljø, eller på arbejdspladsen i kampe for repræsen- tation i organer, der fastlægger f.eks. personalepolitik.

\section{POLITISK ANERKENDELSE I AIDS INDSATSEN}

Det sidste nedslagspunkt handler om den politiske organisering af indsatsen til forebyggelse og bekæmpelse af aids og drejer sig om homoseksuelles muligheder for repræsentation i de velfærdsstatslige institutioner, hvor aids-politikken formuleres og implementeres. Her handler det om politisk anerkendelse. En helhedsorienteret, koordineret og ikke-stigmatiserende indsats over for aids, der ikke kun bygger på et samarbejde mellem hospitalsvæsen, sundhedsmyndigheder samt forskellige interessegrupper, herunder Landsforeningen for Bøsser og Lesbiske, men også på en anerkendelse af aids som et samfundsproblem og -ansvar, iværksættes kun gradvist og først 6-7 år efter, at de første tilfælde af sygdommen registreres (Fouchard m.fl. 2005). Trods sygdommens udvikling i retning af en epidemi og trods lanceringen af en bredspektret plan for bekæmpelse af aids anerkender den lovgivende magt ikke aids som et tilstrækkeligt påtrængende samfundsproblem, der kan udløse ekstraordinære økonomiske bevillinger. Aids betragtes snarere som et 'bøsseproblem', som det overlades til denne gruppe og det involverede hospitalsvæsen at finde økonomiske midler til. Miskendelsen af bøsser via den lovgivende magts nedværdigende og stereotype repræsentation af homoseksuelle mænds seksuelle adfærdsmønstre, der ses som årsag til sygdommens spredning, giver sig udslag i en betydelig statslig underfinansiering af indsatsen mod aids. Konsekvenserne heraf er anskuet fra fordelingsperspektivet bl.a. manglende økonomiske ressourcer til behandling, rådgivning $\mathrm{og}$ oplysning på hospitaler. På et individuelt plan er effekten for mange hiv-smittede bøsser marginalisering eller egentlig deprivation. Dette gælder især unge uden arbej- 
de, uden uddannelse, opsparing eller pension, hvilket kun delvis kompenseres via arbejdsløsheds- og sygedagpenge eller bistandshjælp (Pedersen 2005). Betragtet fra anerkendelsesperspektivet medfører den stereotype repræsentation, hvad der kan kaldes en dobbelt statusundertrykkelse. Udover miskendelsen som bøsse kommer miskendelsen som hiv-smittet eller som potentiel smittebærer (Pedersen 2005: 88), der ofte medfører en individualisering af ansvaret for smittespredning og en anbringelse af bøsser i positionen som syndebukke (Fouchard m.fl. 2005: 71). Fra demokratiperspektivet kan der peges på homoseksuelles manglende representation i de politiske organer, hvor politikken udvikles samtidig med, at bøsser udpeges som en af hovedmålgrupperne for den politiske indsats. Først med 'blødersagen' i 1985, hvor det registreres at smitte er blevet overført gennem donorblod til adskillige heteroseksuelle, xndres bevillingspraksis og den lovgivende magts syn på aids som et samfundsproblem. Det resulterer i en ændring af retningslinjer for aids-politikken og øgede økonomiske ressourcer og som det vigtigste her $\mathrm{i}$ en relativt større demokratisering af de fora, hvor aids-politikken udvikles og implementeres, hvorved homoseksuelles stemmer inkluderes i større udstrækning.

\section{KONKLUSION}

Ud fra den her skitserede analytiske og normative ramme for et retfærdigt seksuelt medborgerskab har det været muligt at sætte spot på en flerhed af begrænsninger på homoseksuelles medborgerskab samt at synliggøre, hvordan begrænsningerne virker sammen. Analysen viser gennem brug af eksempler, at der stadig i både samfundsindretningen og i de mellemmenneskelige relationer eksisterer barrierer, der forhindrer et fuldt og lige medborgerskab for homoseksuelle. Begrænsningerne opstår som følge af retslig miskendelse, kulturel despekt for homoseksuelle og manglen på ho- moseksuelles robuste politiske repræsentation. Disse tre forhold indsnævrer sammen med de økonomiske konsekvenser af dem homoseksuelles mulighed for at deltage i det sociale liv på lige fod med andre. Bedømt ud fra normen, lighed i deltagelse, kan der næppe tales om et retfærdigt seksuelt medborgerskab i Danmark.

Analysen sår tillige tvivl ved det danske samfunds dominerende selvfortælling, der fremstiller samfundet som særdeles seksuelt tolerant, fordomsfrit og ligestillende. Ved siden af det trivielle faktum, at sådanne fortællinger oftest er stærkt forsimplende, kan de også bidrage til at sløre erkendelsen af, at der er tale om reelle samfundsproblemer og tilsvarende at udsætte deres løsning. Selvom homoseksuelle i Danmark på linje med homoseksuelle i andre samfund, bl.a. Holland, Sverige, Norge, Island og Spanien, i både europxisk og ikke mindst global sammenhæng, kan siges at have opnået en større grad af medborgerlig inklusion gennem de sidste tre årtier, forestår der stadig samfundet presserende opgaver. Forskningsmæssigt er der en betydelig vidensmangel om homoseksuelles medborgerskab. Teoretisk er der brug for at arbejde videre med, hvad retfærdighed i en substantiel forstand indebærer, ligesom begrebet seksuelt medborgerskab fordrer en videreudvikling set i lyset af nyere samfundsudviklinger. Politisk er der behov for at opfinde måder, hvorpå seksuel diversitet kan integreres, således at homoseksuelle anerkendes som ligeværdige medborgere inden for et pluralistisk samfund.

\section{NOTER}

1. I et poststrukturalistisk perspektiv er det problemfyldt at tænke i sociale kategorier, 'homoseksuelle' og 'heteroseksuelle'. Det hænger sammen med den anti-essentialisme, der advokeres for ontologisk, og som betyder, at seksuelle identiteter ikke er at forstå som enhedslige og stabile størrelser med iboende fælles egenskaber endsige med 
fælles interesser. Snarere må de betragtes som materielt og immaterielt konstituerede. Politisk bruges kategorierne imidlertid af aktører som betegnelser for seksuelle grupper, der forstås som netop prægivne størrelser. For at løse dette skisma inddrager jeg Youngs (1995) forståelse af sociale grupper. Hun nedbryder en gruppe i tre komponenter: 1) en social kollektivitet, der alene er en passiv konstruktion af individer, der forenes af betingelser samt social praksis; 2 ) et aktivt fællesskab, der opstår ad hoc omkring politiske sager; og 3 ) et egentlig politisk fællesskab i skikkelse af f.eks. sociale bevægelser. Homoseksuelle ser jeg således som en social kollektivitet, der er forenet på en passiv måde uden, at den tilskrives fælles egenskaber, og uden at det forudsættes, at den har en fælles identitet. I Danmark har kollektiviteten udkrystalliseret sig i forskellige politiske fællesskaber, hvoraf Landsforeningen for Bøsser og Lesbiske (LBL) i dag er den eneste, som har karakter af en formel organisation.

2. Se Medborger i Danmark, (medborger i Danmark, 2002)

3. Marshalls (1950) teori har stået centralt i efterkrigstiden og er senere blevet videreudviklet. Bl.a. har kønsforskere, f.eks. Lister (1997), samt seksualitetsforskere, f.eks. Richardson (1998), kritiseret den mandlige, henholdsvis heteroseksuelle norm, som teorien bygger på.

4. Evans (1993) var den første til at anvende begrebet, hvormed han adresserede retten til forskellige seksuelle identiteter og praksisformer.

5. Barry (2001).

6. Young (1990) \& Taylor (1992).

7. Det økonomiske, kulturelle og politiske har karakter af perspektiver, der antager form som en 'triple perspektivisme', og som gør det muligt at analysere enhver social praksis ud fra tre vinkler på samme tid. Til grund ligger den forståelse, at al social praksis har såvel økonomiske og kulturelle som politiske eksistensbetingelser. Empirisk kan det konstateres, at de forskellige uretfærdighedsformer oftest griber ind i hinanden. Se analysen senere samt f.eks. Hobson (2003).

8. Homoseksuelle er en heterogen gruppe, da seksualitet samvirker med andre undertrykkelses- og dominansrelationer. Implikationerne heraf ligger det udenfor denne artikels ærinde at belyse.

9. Andre medborgerskabsteorier er mere ensidige. Republikansk teori ser især medborgerskab som en praksis, mens den liberale og den socialdemokratiske teori overvejende opfatter medborgerskab som en status.

10. Samme idé genfindes hos Fraser i embryonisk form.
11. Begrebet bruges i en 'commonsense' forstand frem for i en analytisk.

12. Jf. note 7 .

13. Stormhøj 2007b.

14. Demokrati er både et led i og en betingelse for retfærdighed. For at kunne se sig som subjekt for retfærdighed må alle, der bliver berørt af en social institution, have mulighed for at deltage i drøftelse og beslutning herom. Det fordrer økonomisk, kulturel og politisk lighed i deltagelse. Hvad det indebærer, savnes der en substantialisering af hos Fraser (Stormhøj 2007a).

15. Disse er valgt, fordi de giver adgang til at belyse væsentlige betingelser for homoseksuelles deltagelsesmæssige lighed inden for den økonomiske, kulturelle og politiske orden. De eksemplificerer aspekter af anerkendelsesrelationerne, som de udtrykkes i familielovgivning, det civile samfund, på arbejdsmarkedet samt i en del af det sundhedspolitiske område. Eftersom anerkendelsesrelationerne inden for stat, marked og civil samfund ikke har en ensartet form, er det ikke muligt ud fra disse eksempler at drage almene slutninger.

16. I den eneste kvantitative undersøgelse, der er gennemført i Danmark, rapporterer 39 pct. af de adspurgte homoseksuelle at have været udsat for diskrimination (Ugebrevet A4 2005). Undersøgelsen er ikke statistisk representativ. Hvis resultater fra repræsentative, svenske og norske undersøgelser kan overføres til Danmark, hvilket ligheder i kulturer og arbejdsmarkeder tilsiger, at de med en vis rimelighed kan, er diskrimination ikke noget ubetydeligt problem. Ca. 25 pct. af norske lesbiske og bøsser hævder at have oplevet diskrimination (Hegna m.fl. 1999), mens det tilsvarende er 36 pct. i en svensk undersøgelse. Yderligere rapporterer mellem 15-20 pct., at de er blevet nægtet ansættelse og nogenlunde samme antal hævder, at de er blevet nægtet forfremmelse på grund af seksuel orientering (SOU 1997: 175).

\section{LITTERATUR}

- Albæk, Erik (1998): Frisindets grænser: Homoseksuelle mellem moralske dilemmaer og politiske hensyn, i Politica 1998/30.

- Barry, Brian (2001): Culture and Equality: An Egalitarian Critique of Multiculturalism. Polity, Cambridge.

- Drud-Jensen, Mads og Sune P. Knudsen (2005):

Ondt $i$ røven. Høst \& Søn, København.

. Evans, David (1993): Sexual Citizenship: The 
Material Construction of Sexualities. Routledge, London.

. Fouchard, Jan m.fl. (2005): Bøssepesten. Historien om aids-bekampelsen blandt bøsser $i$ Danmark 19811996. Borgen, København.

. Fraser, Nancy (1997): Justus interruptus. Critical reflections on the postsocialist condition. Routledge, New York.

- Fraser, Nancy (2003a): Social justice in the age of identity politics, i Nancy Fraser and Axel Honneth: Redistribution or Recognition? A Political-philosophical exchange. Verso, London.

- Fraser, Nancy (2003b): Distorted beyond all recognition: A rejoinder to Axel Honneth, i Nancy Fraser and Axel Honneth: Redistribution or Recognition? A Political-philosophical exchange. Verso, London.

- Fraser, Nancy (2005): Democratic Justice in a Globalizing Age, in New Left Review 2005/36.

- Hegna, Kristinn m.fl.(1999): Levekair og livskvalitet blant lesbiske kvinner og homofile menn. NOVA, Oslo.

- Hobson, Barbara (ed) (2003): Recognition Struggles and Social Movements: Contested Identities, Agency and Power. Cambridge University Press, Cambridge.

- Lister, Ruth (1997): Citizenship: Feminist Perspectives. New York University Press, New York.

- Marshall, Thomas H. (1950): Citizenship and Social Class. Cambridge University Press, Cambridge. - Medborger i Danmark (2002). Lokaliseret (19/2 2008) på http://www.integrationsministeriet.dk/ NR/rdonlyres/BADDE565-9F6D-41A4-972D-

000F15OCB310/0/medborger_i_danmark_dk.pdf - Pedersen, Bodil (2005): Marginalization and power in living with and researching living with hiv, in Outlines 2005/1.

- Phelan, Shane (2001): Sexual strangers. Gays, lesbians and dilemmas of citizenship. Temple University Press, Philadelphia.

- Richardson, Diane (1998): Sexuality and citizenship, in Sociology 1998/32.

- Seidman, Steven (1997): Difference troubles. Queering social theory and sexual politics. Cambridge

University Press, Cambridge.

- SOU (1997): Betänkande om utredningen mot diskriminering $i$ arbetslivet pà grund av sexuell läggning. Fritzes, Stockholm.

- Statens Folkhälsoinstitut (2005): Homosexuellas, bisexuellas och transpersoners hälsosituation. Lokaliseret på http://www.fhi.se

- Stormhøj, Christel (2002): Queering the family: Critical reflections on state-regulated heteronormativity in the Scandinavian countries, i Lambda Nordica 2002/2-3.
- Stormhøj, Christel (2006): Kampen om familien. Homoseksuelle og den danske velfærdsstats styring af reproduktion, i Poststrukturalismer. Videnskabs teori, analysestrategi, kritik. Samfundslitteratur, Frederiksberg.

- Stormhøj, Christel (2007a): Citizenship beyond Formal Equality. Recognition, Participation and Justice for Homosexuals in Denmark (manus). - Stormhøj, Christel (2007b): Perspectives on Homosexuals. Social Standing or against Reductionism (forthcoming).

- Taylor, Charles (1992): The politics of recognition, in Amy Gutmann (ed): Muliticulturalism and the 'Politics of Recognition'. Princeton University Press, Princeton.

- Ugebrevet A4 (2005): Bøsser og lesbiske diskrimineres på jobbet. Lokaliseret (24/08 2008) på http://www.ugebreveta4/smcms/Ugebrevet - Ussing, Peter (2002): Ligestillede som om de er ligeverdige. Speciale, Inst. for Statskundskab, Aarhus Universitet.

- Young, Iris M (1990): Justice and the Politics of Difference. Princeton University Press, Princeton. - Young, Iris M (1995): Gender as seriality: thinking about women as a social collective, i Linda Nicholson and Steven Seidman (eds.): Social postmodernism. Beyond identity politics. Cambridge University Press, Cambridge.

\section{SUMMARY}

The article discusses homosexuals' citizenship in Denmark within a social justice perspective and raises doubt about the society's sexual permissiveness and equality. Drawing on theories of citizenship and social justice, it establishes an analytical and normative framework for a just sexual citizenship based on the norm of participatory parity. Highlighting several institutional barriers for a just sexual citizenship, alongside their intertwinements, it argues for the need for changing the sexual status order and for linking economic, cultural and political remedies for injustice.

Christel Stormhøj, ph.d., lektor Institut for Samfund og Globalisering Roskilde Universitetscenter 